\title{
LUT
}

University

\section{Organizational Trust Dimensions as Antecedents of Organizational Commitment}

\author{
Vanhala Mika, Heilmann Pia, Salminen Hanna
}

This is a Final draft

version of a publication

published by John Wiley \& Sons, Ltd.

in Knowledge and Process Management

DOI: $10.1002 / \mathrm{kpm} .1497$

Copyright of the original publication: (C) 2016 John Wiley \& Sons, Ltd.

Please cite the publication as follows:

Vanhala, M., Heilmann, P., Salminen, H. (2016). Organizational Trust Dimensions as Antecedents of Organizational Commitment. Knowledge and Process Management, vol. 23, iss. 1, pp. 46-61. DOI: 10.1002/kpm.1497

This is the peer reviewed version of the article, which has been published in final form at https:// doi.org/10.1002/kpm.1497. This article may be used for non-commercial purposes in accordance with Wiley Terms and Conditions for Use of Self-Archived Versions.

This is a parallel published version of an original publication. This version can differ from the original published article. 


\title{
Organizational Trust Dimensions as Antecedents of Organizational Commitment
}

\begin{abstract}
This study examines different dimensions of organizational trust as antecedents of employees' organizational commitment. Quantitative survey data from a large forest company $(\mathrm{N}=411)$ and a large ICT company $(\mathrm{N}=304)$ in Finland were collected. A structural equation modelling was used in order to test the hypotheses. The results from both samples demonstrated that impersonal trust dimensions were positively related to organizational commitment. Whereas, interpersonal trust dimensions did not have a significant impact on employees' organizational commitment. Perceived fairness and capability of the organization's policies and practices play an important role in terms of reinforcing employees' organizational commitment.
\end{abstract}

Keywords: Organizational trust, impersonal trust, interpersonal trust, organizational commitment, ICT, paper industry 


\section{Introduction}

Employees are often argued to be the most important asset in organizations' annual reports (Barney and Wright, 1998). Yet, they are usually the first to be influenced by cost reduction and downsizing, for example, in the forms of reduced salaries and headcounts. One outcome of these actions can be a mistrust and a creation of a trust gap between employees and managers (Tyler, 2003), and in the whole organization (Laschinger et al., 2000). This issue is a particularly actual at the moment due to the current economic downturn faced by many Finnish companies. Without the trust of employees, managers and the organization as a whole are likely to see reduced productivity and weakened performance (Zeffane and Connell, 2003). In other words, it has been argued that organizational efficiency is possible when interdependent actors work together effectively in a climate of positive trust (Zeffane and Connell, 2003) enhancing effective communication (Blomqvist, 2002; Shockley-Zalabak et al., 2000), organizational collaboration (Mayer et al., 1995; Tyler, 2003) and accumulation of social capital (Tan and Lim, 2009).

As a concept, organizational trust refers to both trust in individuals and trust in the organization as a whole (Shockley-Zalabak et al., 2000). However, the interpersonal trust has dominated the organizational trust literature and previous studies have mainly focused on trust in managers, neglecting trust between co-workers (Tan and Lim, 2009; Ferres et al., 2004; Tan \& Tan, 2000). Just recently, the attention has shifted towards trust at the organizational level (Searle and Dietz, 2012). Thus, there is increasing interest in the impersonal element of organizational trust (Bachmann, 2006), known as institutional (see e.g. Costigan et al., 1998; McKnight et al., 1998) or systems (Büssing, 2002; Luhmann, 1979) trust. However, the concept of impersonal trust and its underpinnings are not yet clear in the research on organizations. It is used mainly in sociology and economics, and more on the macro level. In management literature, the concept of impersonal trust has only recently emerged in scientific discussion. As a concept, impersonal trust refers to the trust employees have in organizations' structures and processes, as well as in the fairness of its HRM policies and decision-making processes (see Atkinson and Butcher, 2003; Costigan et al., 1998; Kramer, 1999; McKnight et al., 1998; Tan and Tan, 2000). However, it has been studied very little in the organizational context, but some studies have already recognized its impact more or less explicitly (see Atkinson and Butcher, 2003; Costigan et al., 1998; McKnight et al., 2002; Shamir and Lapidot, 2003; Vanhala et al., 2011). For example, impersonal trust has been demonstrated to have an impact on the innovativeness of organizational units (e.g. Ahteela et al., 2010; Ellonen et al., 2008).

This study contributes to trust literature in three different ways. Firstly, organizational trust is studied by focusing on both interpersonal (trust in co-workers and in managers) and impersonal trust (trust in systems). Secondly, different dimensions of interpersonal and impersonal trust are studied as antecedents of organizational commitment. Although there is already studies (see e.g. Bijlsma and Koopman, 2003; Zeffane and Connell, 2003; Aryee et al., 2002; Büssing, 2002; Dirks and Ferrin, 2001) which have revealed trust to be a significant determinant of organizational commitment, there is a lack of empirical evidence on the relationship between different dimensions of organizational trust and organizational commitment. This is important, because it gives indications, how trust-related interventions aiming to increase the organizational commitment of employees should be directed. Thirdly, building employees' trust in the employer can be seen a goal for all kinds of organizations (Zhang et al., 2008). But, trust matters, especially in knowledge-intensive organizations, like ICT companies, because the willingness of knowledge-workers to share knowledge is 
dependent on how fair and trustworthy they perceive their organization (Blomqvist, 2002; Tyler, 2003; Tzortzaki and Mihiotis, 2014). Therefore, the significance of organizational trust dimensions for employees' organizational commitment is studied and compared in two large companies representing different industrial sectors, namely ICT and forest industry.

Hence, in order to address this research gap, the objective of this study is to examine the role of both interpersonal and impersonal trust in employees' commitment to their employer organization. More specifically, we examine which dimensions of organizational trust are linked to employees' organizational commitment. We address this objective by presenting hypotheses, which will be tested by using structural equation modeling among samples from a large forest $(\mathrm{N}=411)$ and ICT company $(\mathrm{N}=304)$ in Finland.

Next, the theoretical framework of this study is discussed followed by methodology. After that, the empirical results are presented. The article concludes with discussion, implications for practice and suggestions for future research.

\section{Theoretical Framework}

\section{Trust within the organization}

The concept of trust can be understood and defined in different ways. First, a distinction can be made between trust as a behavioral intention and trust as an internal action (Colquitt et al., 2007). Second, some writers have used trust as a synonymous with trustworthiness, while others have seen trust as part of personality that develops in childhood (Colquitt et al., 2007). There exists also opposite views about, whether employees can simultaneously demonstrate trust and distrust to a single subject (Saunders et al., 2014). In this study, we rely on the definition presented by Rousseau et al. $(1998,395)$ which states that trust is "a psychological state comprising the intention to accept vulnerability based upon positive expectations of the intentions or behavior of another". These positive expectations are based on perceptions about the other party and its trustworthiness, whereas the intention to accept vulnerability is a risk-taking act. The trusting party relies on the trusted party to do something on their behalf, for example without constant monitoring (see e.g. Dietz and Den Hartog, 2006). According to Rousseau et al. (1998), there are two conditions that must exist for trust to arise: risk and interdependence. Risk is the probability of loss perceived by the trusting party. The connection between trust and risk comes from a reciprocal relationship in that risk creates the opportunity for trust that can subsequently lead to risk taking. Another necessary condition, interdependence, implies that one party's interests cannot be fulfilled without reliance on the other party. (Rousseau et al. 1998.)

In organizational context, trust can be targeted to organization, groups or individuals. (Korsgaard et al. 2008, 89). In other words, one can have trust in particular people (i.e., personal trust) or trust in organized systems (i.e. impersonal trust) (Maguire and Phillips, 2008). This study understands organizational trust broadly covering both interpersonal (Costigan et al., 1998; Mayer and Davis, 1999; Mayer et al., 1995) and impersonal trust (McCauley and Kuhnert, 1992; McKnight et al., 1998; McKnight et al., 2002).

Interpersonal trust is treated as an issue of lateral trust, that is, an employee's trust in other employees and vertical trust, in other words, the trust in immediate supervisors (McCauley and Kuhnert, 1992). However, most trust studies have investigated the vertical trust, neglecting the lateral trust between co-workers (Tan and Lim, 2009). Interpersonal trust may 
be based on the competence, benevolence, or reliability of the other party. The competencebased form of trust refers to trust in another party's skills, abilities, and characteristics: people trust those who they believe can solve problems and deliver desired outcomes (Mayer et al., 1995; Whitener et al., 1998) The benevolence-based form of trust refers to an assumption that the trusted person wants to do good, that is, to act benevolently without succumbing to egocentric or opportunistic behavior. Trust in another party reflects an expectation that the other party has good intentions and demonstrates concern for the welfare of others (Dirks and Ferrin, 2001; Mayer et al., 1995) Reliability-based trust refers to the set of principles that the trustor finds acceptable, in other words, one can rely on the other person's actions and words. Trust in a person's reliability also means expectations that the other party will tell the truth and keep their promises (Mayer et al., 1995; Williams, 2001). In summary, in this study we define interpersonal trust as, the positive expectations of an individual employee of the competence, benevolence, and reliability of their co-workers and immediate managers in line with previous studies (Tan and Lim, 2009; Ferres et al., 2004; Tan and Tan, 2000).

While interpersonal trust is based on interpersonal interaction between individuals within a particular relationship, impersonal trust is based on roles, systems, and reputation. Employees of an organization may draw inferences about impersonal trust from the behavior of highly visible role models like top management (Kramer, 1999). According to Costigan et al. (1998) for most employees, the decision to trust top management is based more on the outcomes of their decisions and less on direct personal experience of their character or actions. For example, McCauley and Kuhnert (1992) point out that trust between employees and management is not interpersonal in nature, but is instead based on roles, rules, and structured relations within the organization. Employees monitor the organizational environment to judge whether to trust management. If the organizational environment encourages a high level of management trust in employees, these employees, in turn, will reciprocate by showing high levels of trust in management. In addition, Blomqvist (1997) states that trusting a person and trusting an organization are two different things. Trust in an organization is based on the way the organization acts, on a particular trustworthy way of behaving. This can stem from a manager's personality or from a strongly centralized decision-making structure, and organizational culture. HRM practices can be also seen as having a central role for influencing employees' trust in their organization (Pucétaité et al., 2010).

Gilbert and Tang (1998) describe organizational trust as an employee's feeling of confidence in and support for an employer: the employee believes that the employer will be open and will honor commitments. It thus refers to the employee's faith in the organization's leadership, and the belief that its goals are attainable and that, ultimately, all of its actions will be beneficial to the workforce. In other words, impersonal trust is understood in this study as the evaluation of an organization's trustworthiness as perceived by the employees, that is, the confidence that the organization will act in a way that is beneficial, or at least not detrimental, to them (see e.g. Atkinson and Butcher, 2003; Maguire and Phillips, 2008; Tan and Tan, 2000). This requires a congruence of the norms and values between both parties. However, the norms and values are embedded on the social and organizational context making organizational trust a context-dependent phenomenon. For example, organizational trust has been demonstrated to be often lower in post-socialist countries than in western countries due to the different socialhistorical processes. (Pucétaité et al., 2010.) In this study, impersonal trust is defined as "the individual employee's expectations about the employer organization's capability and fairness" (Vanhala et al., 2011, 492). 


\section{Organizational commitment}

The concept of organizational commitment is commonly related to high-trust organizational culture (Mathews and Shepherd, 2002). The early conceptualizations were unidimensional, and organizational commitment was seen either as calculative (Becker, 1960) or attitudinal (Mowday et al., 1979). For example, Buchanan (1974) has defined organizational commitment as consisting of three components: identification, involvement, and loyalty. Whereas, Mowday et al. (1979) defined organizational commitment fairly similarly as characterized by three factors: 1) a strong belief in and an acceptance of the organization's goals and values, 2) a willingness to exert considerable effort on behalf of the organization, and 3) a strong desire to maintain membership of the organization. Cook and Wall (1980) have incorporated elements of the definitions presented by Buchanan (1974) and Mowday et al. (1979) by identifying organizational commitment consisting of 1) organizational identification, 2) organizational involvement and 3) organizational loyalty. The first and third components of this definition are similar to those presented by Buchanan (1974). The second component stresses employees' willingness to put effort for the organization's sake (Cook and Wall, 1980), which resembles with one of the component provided by Mowday et al. (1979). Later, Meyer and Allen (1991) presented a model of commitment comprising three components: affective, normative and continuance commitment. Affective organizational commitment can be seen as the employees' emotional attachment to their organization. In other words, employees work to a level beyond that required to obtain the specified reward. Employees with normative commitment feel a moral obligation to remain with the employer organization. Continuance commitment refers to the calculative form of commitment: employees assess the value of maintaining their membership of the organization compared to leaving the organization (Meyer et al., 2002).

Research concerning organizational commitment has been extensive and previous studies have focused mainly on its antecedents, correlates, and consequences (Meyer et al., 2002). The three most often used measures of organizational commitment are: the Organizational Commitment Questionnaire (OCQ) conceptualized by Porter et al. (1976), the British Organizational Commitment Scale (BOCS) created by Cook and Wall (1980) and the Affective Commitment Scale (ACS) developed by Meyer and Allen (1991, which all pursue to reflect the definition of organizational commitment presented by Buchanan (1974). (Mathews and Shepherd, 2002). In this study, we understand organizational commitment as employees' attitudinal commitment toward their organization and measure it with items based on the BOCS scale, which has been used for studying the correlations between trust and organizational commitment (Cook and Wall, 1980).

\section{The link between organizational trust and organizational commitment}

Number of positive work-related attitudes and behaviors have been identified as outcomes of organizational trust (Dirks and Ferrin, 2001). For example, organizational trust has been identified as a critical factor for employees' job satisfaction (Aryee et al., 2002; ShockleyZalabak et al., 2000) and performance (Barney and Hansen, 1994). In this study, we focus on organizational commitment as an outcome of organizational trust. Even though, previous studies indicate that organizational commitment is one of the central consequences of organizational trust (Aryee et al. 2002; Bijlsma and Koopman, 2003; Büssing, 2002), most of the previous studies have focused on a single foci of trust (Tan and Lim, 2009). For example, Ferres et al., (2004) found that trust in coworkers was positively related to employees' affective organizational commitment. Dirks and Ferrin (2001) in their meta-analysis 
demonstrated that interpersonal trust has a significant impact on employees' work-related attitudes (such as organizational commitment) and behaviors. However, they also pointed out that a particular context may determine, whether interpersonal trust has a main or moderating effect on employees' reactions. For example, it can be expected that during a downsizing or mergers, interpersonal trust can have a significant main effect on employees' attitudes and behaviors, whereas, in stable situations, the moderation effect is more likely (Dirks and Ferrin, 2001, 462).

Only a handful of studies (for example, Laschinger et al. 2000; Tan and Tan 2000; Nyhan 1999) have analyzed the influence of both interpersonal and impersonal trust on organizational commitment. Furthermore, the results of these studies have been mixed. For example, Laschinger et al. (2000) analyzed the effects of organizational trust on organizational commitment among Canadian nurses. They used Kanter's (1977, 1993) model of workplace empowerment which incorporates both informal (alliances with supervisors, subordinates etc.) and formal job characteristics (formal job definitions, recognition, flexibility) as well as organizational structures (such as support, enough resources to do one's job, opportunities to learning etc.) Their study demonstrated that the organizational structures contributed most to nurses' empowerment. Empowerment had a direct effect on employees' affective organizational commitment, but also an indirect effect through trust in management. (Laschinger et al., 2000.) Tan and Tan (2000) found also that trust in organization (impersonal trust) was associated with higher organizational commitment and lower turnover intentions, whereas, interpersonal trust (trust in supervisors) correlated positively with innovative behavior and satisfactions with supervisor. Whereas, Nyhan (1999) examined in his study, the antecedents of affective organizational commitment by focusing on both interpersonal and system trust among public sector employees in US. His study demonstrated that interpersonal trust had a stronger positive correlate with affective organizational commitment than system-based trust.

The positive relationships between organizational trust dimensions and organizational commitment have been explained by using different theoretical frameworks such as social exchange and psychological contract theory (Colquit et al., 2007). The concept of the psychological contract can be defined as an exchange agreement of promises and contributions between two parties; an employee, and an employer (Janssens et al., 2003). Psychological contract theory also represents the employment relationship in terms of the subjective belief of employees and employers that a promise has been made (Rousseau, 2011; Rousseau and Schalk, 2000). The theory refers to the implicit, reciprocal rights and obligations that individuals perceive to be part of their exchange relations (Rousseau, 1995; 2011). In other words, employees interpret organizational actions such as HRM practices and the trustworthiness of management as indicative of the organization's commitment to them. As a result, employees reciprocate, for example, by offering commitment to the organization. Their consequent behavioral responses reflect the level of mutual commitment. (Whitener 2001.)

In the psychological contract theory, managers are often seen as representatives of the organization giving signals to employees about the state of the psychological contract (Bowen and Ostroff, 2004). This indicates that when employees trust in managers it can have positive influences on their commitment to the organization. However, psychological contract literature has been criticized for disregarding the influence of co-workers and the collective context, which may influence how employees' evaluate their psychological contracts (CoyleShapiro and Parzefall, 2008). New forms of doing jobs, such as working in teams, have 
tightened the co-operation between employees. Furthermore, social exchanges between employees are likely to strengthen the reciprocal relationship between employees resulting in increased trust and organizational commitment (Ferres et al., 2004).

\section{Hypotheses}

Based on previous above presented theoretical review and evidence from previous trust studies, we assume that different dimensions of interpersonal and impersonal trust can be positively associated with employees' organizational commitment. Thus, we hypothesize:

Hypothesis 1a-c: An employee's trust in the a) competence b) benevolence and c) reliability of their co-workers will be positively associated with organizational commitment.

Hypothesis 2a-c: An employee's trust in the a) competence b) benevolence and c) reliability of their managers will be positively associated with organizational commitment.

Hypothesis 3a-b: An employee's trust in the a) capability and b) fairness of the employer organization will be positively associated with organizational commitment.

\section{Method}

\section{Data Collection and Sampling}

Sample 1 was collected in August-September 2008 from blue-collar workers working in a large forest company in Finland. In total, 700 questionnaires with a covering letter were randomly distributed by the company representatives among the firm's 1,400 employees. We received 411 useable responses from eight units within two of the firm's mills (a 58.7\% response rate). Those units include paper, pulp production and the maintenance service unit. Most of the respondents were men, most had long tenures at the firm, and most did not have a tertiary-level education (see Table 1).

In order to improve the potential generalizability of our findings to different organizational and job contexts, we undertook an additional sample within another industry. The second sample is based on white-collar workers working in a large ICT company in Finland. The data were collected in May-June 2008 from 17 work units within three R\&D centers. Examples of work units in this case included software engineering and hardware planning. A cover letter with a personal link to the questionnaire was sent to 1384 potential respondents via email. A total of 304 completed questionnaires were received, representing a 22\% response rate. Men were again in the majority, but this sample was notably younger and higher educated than the forest company workers, and had been with their current employer for a far shorter period on average (see Table 1). Based on companies' annual HR reports and discussions with the companies' representatives, the demographics of both samples represent the population of the whole workforce of the studied companies.

\section{INSERT TABLE 1 ABOUT HERE}

\section{Measures}


All of the measures were based on a 5-point Likert scale anchored with strongly disagree (1) and strongly agree (5). The items were adopted from earlier studies and further modified, with the help of companies' representatives, in order to make them more understandable in the companies' contexts. (See Appendix 1 for the measures and the wording of the items.)

Independent variable. Organizational trust was analyzed both as an interpersonal and an impersonal form of trust. For the interpersonal form of trust, both trust in co-workers and trust in managers (16 items for both) included three dimensions: competence-based (5 items), benevolence-based (5 items), and reliability-based trust (6 items). The items were adapted with few modifications from Mayer and Davis (1999) and McKnight et al. (2002). A sample item is "The employees/managers in my unit are concerned with my welfare".

Impersonal trust was measured with the 31 items developed, tested, and affirmed by Vanhala et al. (2011). The scale is specifically designed to assess employees' impersonal trust in their employer as an organization. The respondents were asked to indicate how they perceived the statements related to two dimensions of the impersonal form of trust: capability (18 items) and fairness (13 items). The items concerned organizing activities, the sustainability of the organization, top management characteristics, technological reliability, competitiveness, fairness in HRM, fair play in the organization and communication. A sample item is " $M y$ organization functions on such a firm foundation that changes in our business context do not threaten our operations".

Dependent variable. The organizational commitment scale was based on seven items taken from the BOCS (Cook and Wall, 1980) covering identification (two items), loyalty (three items), and involvement (two items). A sample item is "Knowing that my work has made a contribution to the good of the whole organization pleases me".

Control Variables. In the literature on trust and organizational commitment certain differences between individuals have been found to influence their perceptions (see Kuvaas, 2008; Tzafrir et al., 2004). In addition, some demographic variables could influence how commitment is perceived. We therefore used job tenure, age, and the respondent's work unit as control variables in our models. We classified job tenure as under one year, 1-5 years, 6-10 years, 11-15 years, 16-20 years, or over 20 years. Age was classified as under 21 years, 21-30 years, 31-40 years, $41-50$ years, 51-60, or over 60 years. Respondents indicated the unit they worked in on the questionnaire.

\section{Assessment of Bias}

Given the data-collection methods used (the questionnaires were distributed by company representatives and were returned within a single time period), assessment of non-response bias was not possible in sample 1 . However, we were able to conduct an analysis of variance (via ANOVA) on sample 2. It was assumed that those who were among the last to respond most closely resembled non-respondents (Armstrong and Overton, 1977). The early and late respondents were compared on all constructs, and no significant differences between them were found. Thus, non-response bias was not assessed as likely to cause a problem in this study.

The data relied on self-reported measures, and therefore common method variance might have biased the findings. Harman's one-factor test (Podsakoff et al., 2012) was used in order to 
assess the likelihood of such risk. A principal component analysis incorporating all the items from all of the constructs was therefore conducted. The solution was investigated in order to determine the number of factors that would be needed to account for the variance in all of the items: the largest factor accounted for about $30 \%$ of the variance in both samples (Sample 1: $32 \%$ and sample 2: $31 \%$ ). Thus, bias related to common method variance did not seem to be a problem.

\section{Results}

We used Partial Least Squares (PLS) for the analyses (version 2.0M3 of SmartPLS). The first step was to assess the reliability and validity of the measurement models. We then used the structural model to test our hypotheses.

\section{Correlation Analysis}

The means, standard deviations and correlation matrixes are presented in Tables 2 and 3. The mean values in both samples were rather similar. The highest mean scores were found in both samples in terms of co-workers competence indicating that respondents trusted their coworkers' ability to do their jobs. The lowest mean values were for the impersonal trust dimensions, in other words, perceived capability and fairness of the organization. Whereas, trust in managers (trust in their competence, benevolence and reliability) had strong positive correlations with the dimensions of impersonal trust. The mean values of organizational commitment were moderate in both samples. The level of organizational commitment was slightly higher in the ICT company than in the paper company. There were significant correlations between the independent variables (i.e., interpersonal and impersonal trust) and the dependent variable (organizational commitment). This supports our expectation that organizational trust and organizational commitment would be interconnected.

\section{INSERT TABLE 2 ABOUT HERE}

\section{INSERT TABLE 3 ABOUT HERE}

Measurement Models. In order to test the measurement models, we assessed both the internal consistency and the discriminant validity.

Internal consistency. Measures of construct reliability (CR) and convergent validity represent internal consistency. According to the CR test, all the constructs showed a value above the threshold (0.7, adopted by Bagozzi and Yi, 1991) (see Tables 2 and 3). In order to test for convergent validity we examined $\mathrm{CR}$, the factor loading and Average Variance Extracted (AVE). The loadings for the majority of the items were high (with the exception of one item in capability and one item in fairness) and statistically significant (see Appendix 1). This means that they were all related to their specific constructs, verifying the posited relationships among the indicators and constructs. Second, the AVE measure exceeded the cut-off point 0.50 (see Fornell and Larcker, 1981) in most of our constructs (see Tables 4 and 5). However, it fell short for capability, fairness and organizational commitment, but when all the criteria for convergent validity are taken into account this measure is also adequate.

Discriminant validity. This indicates the extent to which any one construct differs from the others, and in assessing it the AVE should be greater than the variance shared between that 
construct and the other constructs in the model (i.e., the squared correlation between two constructs) (Fornell and Larcker, 1981). The constructs of our study fulfill this condition: in our two models (see Tables 4 and 5) the diagonal elements (AVEs) are greater than the offdiagonal elements in the corresponding rows and columns. The only exceptions are capability and fairness in both models and organizational commitment in sample 1 . In sum, the model assessments showed adequate validity and reliability for the operationalization of the concepts.

\section{INSERT TABLE 4 ABOUT HERE}

\section{INSERT TABLE 5 ABOUT HERE}

\section{Testing the research model}

Our research model was capable of explaining 55\% of the variance in sample 1 and $41 \%$ of the variance in sample 2 (see Tables 6 and 7). We estimated path models reflecting the posited relationships between the different elements of organizational trust and organizational commitment to test the hypotheses.

In sample 1 (see Table 6), only one (H1c trust in co-workers' reliability) of the path estimates from the employees' trust in their co-workers to organizational commitment (H1a-H1c) had a significant impact on organizational commitment. However, the impact was contrary to our hypotheses $(\mathrm{B}=-0.113, \mathrm{p}<0.01)$. We also predicted direct paths from different dimensions of trust in managers $(\mathrm{H} 2 \mathrm{a}-2 \mathrm{c})$ and trust in the employer organization $(\mathrm{H} 3 \mathrm{a}-3 \mathrm{~b})$ to organizational commitment. Of those path estimates only two, the capability of the organization (H3a) and fairness of the organization $(\mathrm{H} 3 \mathrm{~b})$, were as expected. The effect of capability $(\mathrm{B}=0.458, p<0.005)$ and fairness $(\mathrm{B}=0.252, p<0.005)$ of the organization were significant and moved in the predicted direction.

The form of support for our hypotheses was rather same in sample 2 (see Table 7). Of the path estimates of employees' trust in co-workers to organizational commitment (H1a-H1c), none had a significant impact on organizational commitment. We also predicted paths from dimensions of trust in managers $(\mathrm{H} 2 \mathrm{a}-2 \mathrm{c})$ to organizational commitment. Again, none of these were significant. Only trust in the employer organization's capability (H3a) and fairness $(\mathrm{H} 3 \mathrm{~b})$ were as hypothesized. The effects of capability $(\mathrm{B}=0.196, p<0.005)$ and of fairness $(0.356, p<0.005)$ of the organization on organizational commitment were significant and moved in the predicted direction.

INSERT TABLE 6 ABOUT HERE

\section{INSERT TABLE 7 ABOUT HERE}

\section{Discussion}

Both organizational trust (Cook and Wall, 1980; Pucétaité et al., 2010) and organizational commitment (Meyer et al., 2002; Mowday et al., 1979) are seen as significant ingredients of organizational effectiveness and the well-being of employees. This study contributed to previous organizational trust studies in three ways. Firstly, we studied organizational trust broadly covering both interpersonal and impersonal aspects of trust. Although it is recognized that trust in organizations operates at multiple levels (Rousseau et al., 1998), there is no clear 
consensus on the concept of trust within the organization. Earlier studies have tested the concept of interpersonal trust (i.e. trust between employees and managers or the top management) and its role in organizational settings, and in different outcomes quite extensively (Costigan et al., 1998; McCauley and Kuhnert, 1992). Whereas, the concept of impersonal trust has attracted less attention among researchers (see Eberl et al., 2012; Searle et al., 2011). Only recently studies have begun to acknowledge the impersonal dimension of organizational trust (Costigan et al., 1998; Maguire and Phillips, 2008; McCauley and Kuhnert, 1992; Tan and Lim, 2009; Vanhala et al., 2011) where employees place trust in their top management team as a unit, and in their organization as a functional structure (e.g. in terms of strategy, vision, and processes).

Secondly, we contributed to the organizational trust literature by analysing both interpersonal and impersonal trust dimensions as antecedents of organizational commitment. To the best of the researchers' knowledge this is one of few studies, and the first systematic large twosample study, to examine the relationship of a) different dimensions of interpersonal trust and b) impersonal trust and organizational commitment. We believe that our findings can provide academics both in human resource management and business strategy, as well as managers and HRM practitioners in organizations, with new knowledge and a more holistic understanding of the linkage between organizational trust and organizational commitment. The specific aim of this study was to show which dimensions of organizational trust are linked most critically to employees' organizational commitment. We developed and tested eight hypotheses to meet the aim. The first three $(\mathrm{H} 1 \mathrm{a}-1 \mathrm{c})$ suggested that trust in co-workers positively affects organizational commitment. The second set of hypotheses (H2a-2c) examined the relationship between trust in managers and organizational commitment. The last set of two hypotheses concerned trust in the employer and organizational commitment. The results of testing these hypotheses for two different empirical studies are summarized in Table 8 .

\section{INSERT TABLE 8 ABOUT HERE}

Thirdly, the findings from the forest and ICT company in Finland validated only two of our hypotheses. According to our analysis, the empirical data supports Hypothesis 3a (the existence of a positive relationship between capability of the employer organization and commitment). In other words, if employees trust that their employer organization is capable (e.g. in terms of competitiveness, top management characteristics, technological reliability) they will be more committed to that employer. The other hypothesis supported was Hypothesis $3 b$ (the existence of a positive relationship between the fairness of the employer organization and commitment). This means that if employees perceive that they can trust the employer to act fairly (e.g. through equitable HRM practices, general fair play and reliable communication) they will feel more loyal to their organization, identify with its goals, and will be willing to get positively involved in its initiatives.

Both of the supported hypotheses concerned trust in the employer organization, that is, impersonal trust. Overall, the results suggest that only impersonal trust had an effect on organizational commitment in the studied samples. This result offers support to psychological contract theory, which argues that employees reflect the positive treatment they receive from their organization back to the organization. In both samples the coefficient of determination for the research models was quite high at $55 \%$ for the forest company and $41 \%$ for the ICT company. 
Thus, the main finding of the current research was that when studying organizational trust dimension by dimension, only impersonal trust was an important factor in terms of enhancing employees' organizational commitment. However, it should be pointed out that all dimensions of organizational trust correlated positively with each other. The rather strong positive correlation between trust in managers and impersonal trust dimensions can be attributed to the fact that employees' often perceive supervisors as representatives of the organization (Bowen and Ostroff, 2004). Therefore, 'a positive spill-over effect' is also possible; when employees trust in their supervisors, they ultimately have also confidence on the organization as a whole (Tan and Tan, 2000).

As far as trust in co-workers or managers was concerned, they did not have a positive effect on the level of organizational commitment. The only statistically significant relationship concerning interpersonal trust was negative. In sample 1, trust in co-workers' reliability was negatively associated with organizational commitment. This result partly contradicts with some previous studies. For example, Cook and Wall (1980) found that blue-collar workers' trust in peers correlated substantially positively with their organizational commitment. Whereas, Büssing (2002) found in a study on employees in different organizations and professions (office workers, IT-managers, nurses, and other healthcare professionals) that personal trust in the supervisor and organization correlated significantly with employees' affective type of commitment to the organization, but did not correlate with the instrumental type of organizational commitment.

It has been stated that employees experience trust differently depending on who their colleagues are and in which part of the organization they are working (Shockley-Zalabak et $a l ., 2000)$. In this study, respondents reported rather high trust in co-workers, which can be explained by the notion of self-categorization, which states that individuals who share similar characteristics, such as ethnic background, age, gender, education or roles of membership, may create demonstrate strong trust in peers than more diverse work groups (Korsgaard et al., 2008; McAllister, 1995). Especially, in the Finnish forest sector, employees have traditionally had a strong feeling of togetherness, reinforced for example, by the strong trade union (Työelämän laatua voi nyt mitata 2014). However, it is also possible that interpersonal trust can have a moderating effect on organizational commitment (Dirks and Ferrin, 2001). For example, Tan and Lim (2009) in their study, found that trust in organization mediated the relationship between trust in coworkers and affective organizational commitment. Therefore, it would be worth investigating in the future, the possible mediating role of interpersonal trust dimensions on organizational commitment.

It should be also pointed out that organizational context is likely to play a significant role in terms of which organizational trust dimensions have significant influence on employees' organizational commitment (Dirks and Ferrin, 2001). For example, the rules and regulations of the organization can influence employees' perceptions about the trustworthiness of a supervisor (Korsgaard et al., 2008, 92). In this study, we focused on employees working in two different sectors, which are likely to differ in terms of regulations, level empowerment and expected supervisory roles.

\section{Practical Implications}

Based on the results of this study, it can be argued that impersonal trust can be used to increase employees' commitment to the organization. In other words, while fostering a close supervisory role and interpersonal trust are critical, organizations could benefit from 
complementary impersonal forms of trust. If employees feel able to trust the organization they work for, they can trust their future to it, even if other employees and supervisors cannot provide sufficient support for the evolution of strong interpersonal trust. If employees can trust the organization without having personalized knowledge of each decision maker and key actor, the organization should be more efficient (Kramer, 1999).

This is especially important if organizations cannot rely solely on interpersonal trust, as when opportunities for face-to-face communication and interpersonal relationship development may be limited because of upheaval caused by a turbulent business environment. Knowledge work and interaction is characterized by complexity, uncertainty, and risk, and is increasingly carried out in temporary and technology-enabled task forces, projects, and virtual teams that draw employees from competence centers. Leaders may have dual roles, working as experts and only part-time as supervisors of other knowledge workers. Such settings provide very limited opportunities for the natural evolution of interpersonal trust. Trust among employees, and between employees and supervisors, may therefore wear very thin (Adler, 2001; Schoorman et al., 2007; Zeffane and Connell, 2003).

Organizations wishing to maintain employees' organizational commitment should pay attention to their daily operations and processes, which influence employees' experiences of organizational trust (Pucétaité et al., 2010). Hence, it is important to develop an HRM system that can foster trust, not only in a particular HRM function (e.g. the personnel department) but throughout the HR practices and processes. Moreover, it is matter of the whole management and even the strategy of the organization. Strategic and managerial actions that support organization-wide policies (e.g. communication, job rotation or performance evaluation) could enhance employees trust in the organization, and through that, employees' commitment to their employer.

\section{Limitations and Future Research}

This study has some limitations due to the chosen research design, context, and measures: those same limitations also serve as a basis for further research directions. First, we collected data from two industries and only in the Finnish context. This limits the generalizability of our results. Therefore, further studies would be required to provide more evidence of whether there are differences in the trust - organizational commitment linkage between different occupations and industries. Further studies might also examine the issue of trust and organizational commitment in different cultural contexts, since trust-related issues may vary considerably between different countries.

A second limitation relates to our cross-sectional data. Based on the theoretical review and previous studies, we assumed that trust precedes organizational commitment. In psychological contract literature, trust has been seen as a mediator between causes (HR practices) and consequences (for example, organizational commitment) (Guest, 1998). In a similar vein, for example, development psychology assumes trust as an antecedent of commitment (Büssing, 2002). However, a longitudinal study would be required to confirm this causal order.

Third, while our tests offered support for the measurement model used, further work could be conducted to improve the discriminant validity between different measures. This relates specifically to the measures for impersonal trust that could be developed to better record this phenomenon. Future studies might examine individuals' propensity to trust. Propensity to trust can be seen as an underlying personality dimension that might significantly influence 
how one perceives trust. In the operationalization of organizational commitment, different measures such as one provided by Meyer and Allen (1991) should be also used. In addition, the understanding of commitment could be broadened to cover occupational commitment as well as commitment to a work group. In line with the study of Saunders et al. (2014), there is also a need to examine the consequences of distrust or 'the absence of trust'. Finally, the use of new concepts such as work engagement as an outcome of trust could provide a new avenue for future research.

\section{References}

Adler P. (2001. Market, hierarchy, and trust: The knowledge economy and the future of capitalism. Organization Science 12(2): 215-234.

Ahteela R, Blomqvist K, Puumalainen K, Jantunen A. 2010. HRM practices, innovativeness and performance: The mediating role of organisational trust. International Journal of Strategic Change Management 2(2-3): 241-261.

Armstrong JS, Overton TS. 1977. Estimating Nonresponse Bias in Mail Surveys. Journal of Marketing Research 14: 396-402.

Aryee S, Budhwar PS, Chen ZX. 2002. Trust as a mediator of the relationship between organizational justice and work outcomes: Test of a social exchange model. Journal of Organizational Behavior 23(3): 267-285.

Atkinson S, Butcher D. 2003. Trust in managerial relationships. Journal of Managerial Psychology 18(4): 282-304.

Bachmann R. 2006. Trust and/or power: Towards a sociological theory of organizational relationships. In Handbook of Trust Research, Bachmann R, Zaheer A. (ed.). Edward Elgar: Cheltenham: 393-408.

Bagozzi RP, Yi Y. 1991. Multitrait-multimethod matrices in consumer research. Journal of Consumer Research 17: 426-439.

Barney JB, Hansen MH. 1994. Trustworthiness as a source of competitive advantage. Strategic Management Journal 15(S1): 175-190.

Barney JB, Wright PM. 1998. On becoming a strategic partner: The role of human resources in gaining competitive advantage. Human Resource Management 37(1): 31-46.

Becker HS. 1960. Notes on the Concept of Commitment. The American Journal of Sociology 66: 32-40.

Bijlsma K, Koopman P. 2003. Introduction: trust within organisations. Personnel Review 32 (5): 543-555.

Blomqvist K. 1997. The many faces of trust. Scandinavian Journal of Management 13(3): 271-286.

Blomqvist K. 2002. Partnering in the dynamic environment: The role of trust in asymmetric technology partnership formation. $\mathrm{PhD}$ Dissertation. Lappeenranta University of Technology: Lappeenranta.

Bowen DE, Ostroff C. 2004. Understanding HRM-firm performance linkages: The role of the "strength" of the HRM system. Academy of Management Review 29(2): 203-221.

Buchanan B. 1974. Building organizational commitment: The socialization of managers in work organizations. Administrative Science Quarterly 19(4): 533-546.

Büssing A. 2002. Trust and its relations to commitment and involvement in work and organizations. SA Journal of Industrial Psychology 28(4): 36-42.

Colquitt JA, Scott BA, LePine JA. 2007. Trust, trustworthiness, and trust propensity: A metaanalytic test of their unique relationships with risk taking and job performance. Journal of Applied Psychology 92(4): 909-927. 
Cook J, Wall TD. 1980. New work attitude measures of trust, organizational commitment, and personal need non-fulfillment. Journal of Occupational Psychology, Vol. 53: 39-52.

Costigan RD, Ilter SS, Berman JJ. 1998. A multi-dimensional study of trust in organisations. Journal of Managerial Issues 10: 303-317.

Coyle-Shapiro, JA-M, Parzefall M. 2008. Psychological contracts. In The SAGE handbook of organizational behavior, Cooper CL, Barling J. (ed.). SAGE Publications: London: $17-34$.

Dietz G, Den Hartog DN. 2006. Measuring trust inside organisations. Personnel Review 35(5): 557-588.

Dirks, KT, Ferrin DL. 2001. The role of trust in organizational settings. Organization Science 12(4): 450-467.

Eberl P, Clement U, Möller H. 2012. Socialising employees' trust in the organisation: an exploration of apprentices' socialisation in two highly trusted companies. Human Resource Management Journal 22(4): 343-359.

Ellonen R, Blomqvist K, Puumalainen K. 2008. The role of trust in organisational innovativeness. European Journal of Innovation Management 11(2): 160-181.

Ferres N, Connell J, Travaglione A. 2004. Co-worker trust as a social catalyst for constructive employee attitudes. Journal of Managerial Psychology 19(6), 608-622.

Fornell C, Larcker DF. 1981. Evaluating structural equation models with unobservable variables and measurement error. Journal of Marketing Research 18(1): 39-50.

Gilbert JA, Tang TLP. 1998. An examination of organizational trust antecedents. Public Personnel Management 27: 321-336.

Guest DE. 1998. Is the psychological contract worth taking seriously? Journal of Organizational Behavior 19(S1): 649-664.

Janssens M, Sels L, Van den Brande I. 2003. Multiple types of psychological contracts: A six-cluster solution. Human Relations 56(11): 1349-1378.

Kanter RM. 1977. Men and Women of the Corporation. Basic Books: New York.

Kanter RM. 1993. Men and Women of the Corporation (2d ed). Basic Books: New York.

Korsgaard, MA, Pitariu, AH, Jeong, SS. 2008. Trust in Management: An interpersonal perspective. In The SAGE handbook of organizational behavior, Cooper CL, Barling J. (ed.). SAGE Publications: London: 89-105.

Kramer RM. 1999. Trust and distrust in organizations: Emerging perspectives and enduring questions. Annual Review of Psychology 50: 569-598.

Kuvaas B. 2008. An exploration of how the employee-organization relationship affects the linkage between perception of developmental human resource practices and employee outcomes. Journal of Management Studies 45(1): 1-25.

Laschinger HKS, Finegan J, Shamian J, Casier S. 2000. Organizational trust and empowerment in restructured healthcare settings: Effects on staff nurse commitment. Journal of Nursing Administration 30(9):413-425.

Luhmann N. 1979. Trust and power, Wiley: Chichester.

Maguire S, Phillips N. 2008. Citibankers' at Citigroup: A study of the loss of institutional trust after a merger. Journal of Management Studies 45(2): 372-401.

Mathews BP, Shepherd JL. 2002. Dimensionality of Cook and Wall's (1980) British Organizational Commitment Scale revisited. Journal of Occupational and Organizational Psychology 75(3): 369-375.

Mayer R, Davis JH, Schoorman FD. 1995. An integrative model of organizational trust. Academy of Management Review 20(5): 709-734.

Mayer RC, Davis JH. 1999. The effect of the performance appraisal system on trust for management: A field quasi-experiment. Journal of Applied Psychology 84(1): 123136. 
McAllister, DJ. 1995. Affect- and cognition-based trust as foundations for interpersonal cooperation in organizations. Academy of Management Journal 38(1), 24-59.

McCauley DP, Kuhnert KW. 1992. A theoretical review and empirical investigation of employee trust in management. Public Administration Quarterly 16(2): 265-284.

McKnight DH, Choudhury V, Kacmar C. 2002. Developing and validating trust measures for e-commerce: An integrative typology. Information Systems Research 13(3): 334-361.

McKnight DH, Cummings LL, Chervany NL. 1998. Initial trust formation in new organizational relationships. Academy of Management Review 23(3): 473-490.

Meyer JP, Allen NJ. 1991. Three-Component Conceptualization of Organizational Commitment. Human Resource Management Review 1(1): 61-89.

Meyer JP, Stanley DJ, Herscovitch L, Topolnytsky L. 2002. Affective, continuance, and normative commitment to the organization: A meta-analysis of antecedents, correlates, and consequences. Journal of Vocational Behavior 61(1): 20-52.

Mowday R, Steers R, Porter L. 1979. The measurement of organizational commitment, Journal of Vocational Behavior 14(2): 224-247.

Nyhan RC. 1999. Increasing affective organizational commitment in public organizations: The key role of interpersonal trust. Review of Public Personnel Administration 19(3): 58-70.

Podsakoff PM, MacKenzie SB, Podsakoff NP. 2012. Sources of method bias in social science research and recommendations on how to control it. Annual Review of Psychology 65: 539-569.

Porter LW, Crampon W, Smith F. 1976. Organizational commitment and managerial turnover: A longitudinal Study. Organizational Behavior and Human Performance 15 (1): 87-98.

Pucétaité R, Lämsä A-M, Novelskaité A. 2010. Building organizational trust in a low-trust societal context. Baltic Journal of Management 5(2): 197-217.

Rousseau DM. 1995. Psychological contracts in organizations. Sage: London.

Rousseau D. 2011. The individual-organization relationship: the psychological contract. In APA Handbook of Industrial and Organizational Psychology, $3^{\text {rd }}$ Edition, Zedeck, S. (ed.) American Psychological Association: Washington, DC: 191-220.

Rousseau D, Schalk R. 2000. Psychological contracts in employment. Cross-national perspectives. Sage Publications: Thousand Oaks, CA.

Rousseau DM, Sitki SB, Burt RS, Camerer CF. 1998. Not so different after all: A crossdiscipline view of trust. Academy of Management Review 23(3), 393-404.

Saunders MNK, Dietz G, Thornhill A. 2014. Trust and distrust: Polar opposites, or independent but co-existing? Human Relations 67(6), 639-665.

Schoorman FD, Mayer RC, Davis JH. 2007. An integrative model of organizational trust: past, present and future. Academy of Management Review 32(2), 344-354.

Shamir B, Lapidot Y. 2003. Trust in organizational superiors: Systematic and collective considerations. Organization Studies 24(3), 463-491.

Shockley-Zalabak P, Ellis K, Winograd G. 2000. Organizational trust: What it means, why it matters. Organization Development Journal 18(4), 35-48.

Searle R, Den Hartog D, Weibe A, Gillespie N, Six N, Hatzakis T, Skinner D. 2011. Trust in employer: the role of high-involvement work practices and procedural justice in European organizations. The International Journal of Human Resource Management 22(5), 1069-1092.

Searle RH, Dietz G. 2012. Editorial: Trust and HRM: Current insights and future directions. Human Resource Management Journal 22(4), 333-342.

Tan HH, Lim AKH. 2009. Trust in coworkers and trust in organizations", The Journal of Psychology 143(1), 45-66. 
Tan HH, Tan CSF. 2000. Toward the differentiation of trust in supervisor and trust in organization. Genetic, Social, and General Psychology Monographs 126(2), 241-260.

Tyler TR. 2003. Trust within organisations. Personnel Review 32(5), 556-568.

Tzafrir SS, Harel GH, Baruch Y, Dolan SI. 2004. The consequences of emerging HRM practices for employees' trust in their managers. Personnel Review 33(6), 628-647.

Tzortzaki, AM, Mihiotis, A. 2014. A review of knowledge theory and future directions. Knowledge and Process Management 21(1), 29-41.

Työelämän laatua voi nyt mitata [The quality of working life can now be measured]. 2014. Paperiliitto https://www.digipaper.fi/paperiliitto/124913/index.php?pgnumb=6/Retrieved May 22, 2015.

Vanhala M, Puumalainen K, Blomqvist K. 2011. Impersonal trust - the development of the construct and the scale. Personnel Review 40(4), 485-513.

Resource Management Review 7(4), 389-404.

Whitener EM. 2001. Do "high commitment" human resource practices affect employee commitment? A cross-level analysis using hierarchical linear modeling. Journal of Management 27(5), 515-535.

Whitener EM, Brodt SE, Korsgaard MA, Werner JM. 1998. Managers as initiators of trust: An exchange relationship framework for understanding managerial trustworthy behavior. Academy of Management 23(3), 513-530.

Williams M. 2001. In whom we trust: Group membership as an effective context for trust development. Academy of Management Review 26(3), 377-396.

Zeffane R, Al Zarooni HAM. 2012. Empowerment, trust, and commitment: The moderating role of work-unit centrality. International Journal of Management 29(1), 332-351.

Zeffane R, Connell J. 2003. Trust and HRM in the new millennium. International Journal of Human Resource Management 14(1), 3-11.

Zhang AY, Tsui AS, Song LJ, Li C, Jia L. 2008. How do I trust thee? The employeeorganization relationship, supervisory support, and middle manager trust in the organization. Human Resource Management 47(1), 111-132. 
Table 1 Profile of the respondents (in percentages)

\begin{tabular}{|c|c|c|}
\hline & Sample 1 & Sample 2 \\
\hline \multicolumn{3}{|l|}{ Gender } \\
\hline Men & 79.3 & 84.9 \\
\hline Women & 18 & 14.8 \\
\hline \multicolumn{3}{|l|}{ Age } \\
\hline $21-30$ & 7.8 & 21.1 \\
\hline $31-40$ & 23.4 & 53.3 \\
\hline $41-50$ & 39.9 & 21.1 \\
\hline $51-60$ & 25.8 & 2.3 \\
\hline \multicolumn{3}{|l|}{ Education } \\
\hline Vocational education & 63 & 2.3 \\
\hline Further education qualification & 8.5 & 39.1 \\
\hline Higher education qualification & 4.9 & 45.1 \\
\hline \multicolumn{3}{|l|}{ Tenure } \\
\hline Less than 10 years & 0.2 & 78.9 \\
\hline $11-15$ years & 14.4 & 11.2 \\
\hline $16-20$ years & 13.6 & 3.3 \\
\hline More than 20 years & 52.3 & 6.3 \\
\hline \multicolumn{3}{|l|}{ Job position } \\
\hline Employees & 72.5 & 80.6 \\
\hline 'Officials' & 14.8 & 2.9 \\
\hline Team Leaders & 6.1 & - \\
\hline Managers & 3.6 & 16.1 \\
\hline
\end{tabular}

Table 2 Correlation matrix: sample 1

\begin{tabular}{|c|c|c|c|c|c|c|c|c|c|c|}
\hline & Mean & $S D$ & 1 & 2 & 3 & 4 & 5 & 6 & 7 & 8 \\
\hline $\begin{array}{l}\text { 1. Co-workers' } \\
\text { competence }\end{array}$ & 4.16 & 0.66 & & & & & & & & \\
\hline $\begin{array}{l}\text { 2. Co-workers' } \\
\text { benevolence }\end{array}$ & 3.45 & 0.80 & $.541 * *$ & & & & & & & \\
\hline $\begin{array}{l}\text { 3. Co-workers' } \\
\text { reliability }\end{array}$ & 3.71 & 0.76 & $.624 * *$ & $.774 * *$ & & & & & & \\
\hline $\begin{array}{l}\text { 4. Managers' } \\
\text { competence }\end{array}$ & 3.80 & 0.84 & $.569 * *$ & $.363 * *$ & $.413 * *$ & & & & & \\
\hline $\begin{array}{l}\text { 5. Managers' } \\
\text { benevolence }\end{array}$ & 3.39 & 0.87 & $.359 * *$ & $.559 * *$ & $.427 * *$ & $.654 * *$ & & & & \\
\hline $\begin{array}{l}\text { 6. Managers' } \\
\text { reliability }\end{array}$ & 3.45 & 0.91 & $.395^{* *}$ & $.425 * *$ & $.504 * *$ & $.707 * *$ & $.797 * *$ & & & \\
\hline $\begin{array}{l}\text { 7. Capability of the } \\
\text { organization }\end{array}$ & 3.20 & 0.63 & $.416^{* *}$ & $.321 * *$ & $.334 * *$ & $.587 * *$ & $.572 * *$ & $.637 * *$ & & \\
\hline $\begin{array}{l}\text { 8. Fairness of the } \\
\text { organization }\end{array}$ & 3.03 & 0.62 & $.303 * *$ & $.413^{* *}$ & $.370^{* *}$ & $.556^{* * *}$ & $.650 * *$ & $.720 * *$ & $.750 * *$ & \\
\hline 9. Commitment & 3.26 & 0.78 & $.276^{* *}$ & $.224 * *$ & $.200 * *$ & $.479 * *$ & $.462 * *$ & $.493 * *$ & $.681 * *$ & $.599 * *$ \\
\hline
\end{tabular}

Notes: ** Correlation is significant at the 0.01 level; * Correlation is significant at the 0.01 level 
Table 3 Correlation matrix: sample 2

\begin{tabular}{|c|c|c|c|c|c|c|c|c|c|c|}
\hline & Mean & $S D$ & 1 & 2 & 3 & 4 & 5 & 6 & 7 & 8 \\
\hline $\begin{array}{l}\text { 1. Co-workers' } \\
\text { competence }\end{array}$ & 4.01 & 0.67 & & & & & & & & \\
\hline $\begin{array}{l}\text { 2. Co-workers' } \\
\text { benevolence }\end{array}$ & 3.63 & 0.72 & $.555^{* *}$ & & & & & & & \\
\hline $\begin{array}{l}\text { 3. Co-workers' } \\
\text { reliability }\end{array}$ & 3.81 & 0.68 & $.642 * *$ & $.714 * *$ & & & & & & \\
\hline $\begin{array}{l}\text { 4. Managers' } \\
\text { competence }\end{array}$ & 3.54 & 0.97 & $.595^{* *}$ & $.428 * *$ & $.479 * *$ & & & & & \\
\hline $\begin{array}{l}\text { 5. Managers' } \\
\text { benevolence }\end{array}$ & 3.47 & 0.95 & $.458 * *$ & $.643 * *$ & $.518 * *$ & $.696^{* *}$ & & & & \\
\hline $\begin{array}{l}\text { 6. Managers' } \\
\text { reliability }\end{array}$ & 3.54 & 0.90 & $.487 * *$ & $.509 * *$ & $.677 * *$ & $.742 * *$ & $.792 * *$ & & & \\
\hline $\begin{array}{l}\text { 7. Capability of the } \\
\text { organization }\end{array}$ & 3.27 & 0.62 & $.395^{* *}$ & $.378 * *$ & $.404 * *$ & $.586^{* *}$ & $.565^{* *}$ & $.598 * *$ & & \\
\hline $\begin{array}{l}\text { 8. Fairness of the } \\
\text { organization }\end{array}$ & 3.30 & 0.65 & $.392 * *$ & $.439 * *$ & $.470 * *$ & $.635 * *$ & $.647 * *$ & $.722 * *$ & $.692 * *$ & \\
\hline 9. Commitment & 3.46 & 0.64 & $.295 * *$ & $.345^{* *}$ & $.338 * *$ & $.470 * *$ & $.474 * *$ & $.486^{* * *}$ & $.500 * *$ & $.565^{* *}$ \\
\hline
\end{tabular}

Notes: ** Correlation is significant at the 0.01 level; * Correlation is significant at the 0.01 level

Table 4 Discriminant validity: sample 1

\begin{tabular}{|c|c|c|c|c|c|c|c|c|c|}
\hline & 1 & 2 & 3 & 4 & 5 & 6 & 7 & $\delta$ & 9 \\
\hline $\begin{array}{l}\text { 1. Co-workers' } \\
\text { competence }\end{array}$ & .69 & & & & & & & & \\
\hline $\begin{array}{l}\text { 2. Co-workers' } \\
\text { benevolence }\end{array}$ & 0.29 & .67 & & & & & & & \\
\hline $\begin{array}{l}\text { 3. Co-workers' } \\
\text { reliability }\end{array}$ & 0.39 & 0.60 & .68 & & & & & & \\
\hline $\begin{array}{l}\text { 4. Managers' } \\
\text { competence }\end{array}$ & 0.32 & 0.13 & 0.17 & .75 & & & & & \\
\hline $\begin{array}{l}\text { 5. Managers' } \\
\text { benevolence }\end{array}$ & 0.13 & 0.31 & 0.18 & 0.43 & .72 & & & & \\
\hline $\begin{array}{l}\text { 6. Managers' } \\
\text { reliability }\end{array}$ & 0.16 & 0.18 & 0.25 & 0.50 & 0.64 & .72 & & & \\
\hline $\begin{array}{l}\text { 7. Capability of } \\
\text { the organization }\end{array}$ & 0.17 & 0.10 & 0.11 & 0.34 & 0.33 & 0.41 & .40 & & \\
\hline $\begin{array}{l}\text { 8. Fairness of the } \\
\text { organization }\end{array}$ & 0.09 & 0.17 & 0.14 & 0.31 & 0.42 & 0.52 & 0.56 & .39 & \\
\hline 9.Commitment & 0.08 & 0.05 & 0.04 & 0.23 & 0.21 & 0.24 & 0.46 & 0.36 & .44 \\
\hline
\end{tabular}

Notes: AVE associated with the construct is presented diagonally. The squared correlations between the constructs are presented in the lower left triangle. 
Table 5 Discriminant validity: sample 2

\begin{tabular}{|c|c|c|c|c|c|c|c|c|c|}
\hline & 1 & 2 & 3 & 4 & 5 & 6 & 7 & 8 & 9 \\
\hline $\begin{array}{l}\text { 1. Co-workers' } \\
\text { competence }\end{array}$ & .65 & & & & & & & & \\
\hline $\begin{array}{l}\text { 2. Co-workers' } \\
\text { benevolence }\end{array}$ & 0.31 & 0.58 & & & & & & & \\
\hline $\begin{array}{l}\text { 3. Co-workers' } \\
\text { reliability }\end{array}$ & 0.41 & 0.51 & .63 & & & & & & \\
\hline $\begin{array}{l}\text { 4. Managers' } \\
\text { competence }\end{array}$ & 0.35 & 0.18 & 0.23 & .80 & & & & & \\
\hline $\begin{array}{l}\text { 5. Managers' } \\
\text { benevolence }\end{array}$ & 0.21 & 0.41 & 0.27 & 0.48 & .71 & & & & \\
\hline $\begin{array}{l}\text { 6. Managers' } \\
\text { reliability }\end{array}$ & 0.24 & 0.26 & 0.46 & 0.55 & 0.63 & .70 & & & \\
\hline $\begin{array}{l}\text { 7. Capability of } \\
\text { the organization }\end{array}$ & 0.16 & 0.14 & 0.16 & 0.34 & 0.32 & 0.36 & .39 & & \\
\hline $\begin{array}{l}\text { 8. Fairness of the } \\
\text { organization }\end{array}$ & 0.15 & 0.19 & 0.22 & 0.40 & 0.42 & 0.52 & 0.48 & .37 & \\
\hline 9. Commitment & 0.09 & 0.12 & 0.11 & 0.22 & 0.22 & 0.24 & 0.25 & 0.32 & .37 \\
\hline
\end{tabular}

Notes: AVE associated with the construct is presented diagonally. The squared correlations between the constructs are presented in the lower left triangle.

Table 6 Testing the research model: sample 1

\begin{tabular}{lcc} 
Path & Path coefficient & t-value \\
\hline Control variables & & \\
Tenure $\rightarrow$ Commitment & $-.086^{*}$ & 1.811 \\
Age $\rightarrow$ Commitment & $.179^{* * *}$ & 3.832 \\
Unit $\rightarrow$ Commitment & -.004 n.s. & .187 \\
Dependent variable & & \\
Co-workers' competence $\rightarrow$ Commitment & .062 n.s. & 1.35 \\
Co-workers' benevolence $\rightarrow$ Commitment & .017 n.s. & .407 \\
Co-workers' reliability $\rightarrow$ Commitment & $-.113^{* *}$ & 2.046 \\
Managers' competence $\rightarrow$ Commitment & .067 n.s. & 1.482 \\
Managers' benevolence $\rightarrow$ Commitment & .009 n.s. & .182 \\
Managers' reliability $\rightarrow$ Commitment & .021 n.s. & .444 \\
Capability of the organization $\rightarrow$ Commitment & $.458^{* * *}$ & 7.623 \\
Fairness of the organization $\rightarrow$ Commitment & $.252^{* * *}$ & 4.278 \\
$R^{2}$ & & .545 \\
\hline
\end{tabular}

Notes: *** Significance $<0.005 ; * *$ Significance $<0.01 ; *$ Significance $<0.05$ 
Table 7 Testing the research model: sample 2

\begin{tabular}{lcc}
\hline Path & Path coefficient & t-value \\
\hline Control variables & & \\
Tenure $\rightarrow$ Commitment & -.075 n.s. & 1.515 \\
Age $\rightarrow$ Commitment & -.033 n.s. & .902 \\
Unit $\rightarrow$ Commitment & -.022 n.s. & .701 \\
Dependent variable & & \\
Co-workers' competence $\rightarrow$ Commitment & .073 n.s. & 1.110 \\
Co-workers' benevolence $\rightarrow$ Commitment & .000 n.s. & .002 \\
Co-workers' reliability $\rightarrow$ Commitment & -.000 n.s. \\
Managers' competence $\rightarrow$ Commitment & .116 n.s. & .002 \\
Managers' benevolence $\rightarrow$ Commitment & .120 n.s. & 1.457 \\
Managers' reliability $\rightarrow$ Commitment & -.123 n.s. & 1.305 \\
Capability of the organization $\rightarrow$ Commitment & $.196^{* *}$ & 1.225 \\
Fairness of the organization $\rightarrow$ Commitment & $.356^{* * *}$ & 2.488 \\
$R^{2}$ & & 4.115 \\
\hline
\end{tabular}

Notes: *** Significance $<0.005 ; * *$ Significance $<0.01 ; *$ Significance $<0.05$

Table 8 Summary of the findings

\begin{tabular}{lcc}
\hline \multicolumn{1}{c}{ Hypotheses } & Sample 1 & Sample 2 \\
\hline $\begin{array}{l}\text { Hypothesis 1a: Employee's trust in competence of the co-workers will be } \\
\text { positively associated with commitment. }\end{array}$ & Not supported & Not supported \\
$\begin{array}{l}\text { Hypothesis 1b: Employee's trust in benevolence of the co-workers will } \\
\text { be positively associated with commitment. }\end{array}$ & Not supported & Not supported \\
$\begin{array}{l}\text { Hypothesis 1c: Employee's trust in reliability of the co-workers will be } \\
\text { positively associated with commitment. }\end{array}$ & Not supported & Not supported \\
$\begin{array}{l}\text { Hypothesis 2a: Employee's trust in competence of the managers will be } \\
\text { positively associated with commitment. }\end{array}$ & Not supported & Not supported \\
$\begin{array}{l}\text { Hypothesis 2b: Employee's trust in benevolence of the managers will be } \\
\text { positively associated with commitment. }\end{array}$ & Not supported & Not supported \\
$\begin{array}{l}\text { Hypothesis 2c: Employee's trust in reliability of the managers will be } \\
\text { positively associated with commitment. }\end{array}$ & Not supported & Not supported \\
$\begin{array}{l}\text { Hypothesis 3a: Employee's trust in capability of the employer } \\
\text { organization will be positively associated with commitment. }\end{array}$ & Supported & Supported \\
$\begin{array}{l}\text { Hypothesis 3b: Employee's trust in fairness of the employer organization } \\
\text { will be positively associated with commitment. }\end{array}$ & Supported & Supported \\
\hline & & \\
\hline
\end{tabular}

